\title{
16
}

\section{Crowdfunding in Europe: Between Fragmentation and Harmonization}

\section{Karsten Wenzlaff, Ana Odorović, Tania Ziegler, and Rotem Shneor}

\section{Introduction}

In recent years, Europe has retained its position as the third largest global market for crowdfunding. Similar to other regional markets, it is dominated by a single country accounting for the majority of related volumes,

K. Wenzlaff $(\bowtie)$

Faculty of Business, Economics, and Social Sciences, University of Hamburg, Chair Digital Markets, Hamburg, Germany e-mail: karsten.wenzlaff@uni-hamburg.de

\section{A. Odorović}

Faculty of Law, Institute for Law and Economics, University of Hamburg, Hamburg, Germany

e-mail: ana.odorovic@ile-graduateschool.de

T. Ziegler

Cambridge Centre for Alternative Finance, Judge Business School, University of Cambridge, Cambridge, UK

e-mail: t.ziegler@jbs.cam.ac.uk

R. Shneor

School of Business and Law, University of Agder, Kristiansand, Norway e-mail: rotem.shneor@uia.no 
namely the UK. Overall, European crowdfunding volumes were estimated at USD 18 billion in 2018, growing 51\% from an estimated volume of 11.9 billion in 2017 (Ziegler et al. 2020). However, the UK accounted for 10.4 billion in 2018, while growing 30\% from the USD 8 billion it recorded in 2017. Accordingly, mainland Europe (including 44 countries) has exhibited a dramatic growth of $95 \%$ from a total volume of 3.9 billion in 2017 to 7.6 billion in 2018 .

Several intriguing features characterize crowdfunding in Europe, which essentially capture different facets of the market fragmentation. First, in global comparison, the UK, as the leading regional market, accounts for a smaller proportion of regional volumes (58\% in 2018) than the US does in the Americas (96\% in 2018) or China in the Asia Pacific region (97\% in 2018). In Europe, a wider distribution of volumes across national markets is evident with the Netherlands, Germany, and France as dominant players. Other countries with large volumes, such as Italy, Spain, or Poland, Sweden, Italy, or Belgium are following closely.

Second, cross-border transactions are limited, and usually associated with non-investment models like reward and donation crowdfunding, where regulatory barriers are minimal. However, Europe has thus far failed to produce a European equivalent to global US-based platforms in these spheres (e.g. Kickstarter, Indiegogo, or GoFundMe) with relevant platforms maintaining local focus and anchoring, while competing with the US-based actors on localized features and services (e.g. language, payment systems, customer support, currency). Moreover, most platforms operating investment models, as in equity-based and debt-based crowdfunding, operate only in one country, partially due to the fragmented regulatory landscape within Europe. However, most European countries represent relatively small domestic markets, where local platforms may struggle to achieve sufficient scale towards profitability without international reach.

Against this backdrop, the European Union has created a unified crowdfunding regulation for equity- and lending-based crowdfunding (European Commission 2018c; European Parliament 2019). The ambition of the European Crowdfunding Service Provider (hereafter 'ECSP') Regime has been to improve access to finance for SMEs across Europe, 
while paving the way towards fewer limitations on cross-border investment activity within the continent. During the deliberation and negotiation process, the proposal morphed from a so-called opt-in regime to a binding regime for platforms in all member states, constituting a possible source of harmonization and thus reduction of fragmentation in the market starting in 2021, when the regime will come into force.

This chapter's structure is as follows. In the coming section, we first present the current state of crowdfunding markets in Europe, especially with regards to differences between national markets. Next, the principles of the ECSP Regime proposal are presented, and expectations about its impact are outlined. These discussions are supported by insights from research conducted in European countries. We conclude this chapter with a list of suggestions for further research, as well as implications for practitioners in the region.

\section{The Current State of the European Crowdfunding Market}

In the current section we present the state of European crowdfunding market. Unless otherwise stated, all data presented are adopted from the Cambridge Centre for Alternative Finance (hereafter 'CCAF') Global Alternative Finance Report (Ziegler et al. 2020) and the Fourth Annual European Alternative Finance Report (Ziegler et al. 2019).

In 2017, 597 European platforms have overseen a market turnover of USD 10.4 billion. In 2018, these figures have grown to 794 platforms overseeing a market volume of USD 18 billion. The majority of platforms are concentrated in the relatively larger Western European economies of the UK (89 platforms), Germany (63 platforms), France (51 platforms), Italy (51 platforms), the Netherlands ( 45 platforms) and Spain (39 platforms), with a majority of which domestically based. On the other end, Southern and Eastern European countries were served by less than 10 platforms, most of which were foreign-based. Some explanations for this may be found in a study by Dushnitsky et al. (2016), who examined the conditions associated with platform creation at the national 
level during the early years of the European crowdfunding industry (2008-2014). This study showed that platforms are more likely to be created in countries characterized by larger market sizes (in terms of population), higher entrepreneurship rates (in terms of share of population owning a new business), as well as where traditional financial institutions are involved (in terms of percentage of active platforms operated by established financial organizations) providing the new industry with a degree of legitimacy.

Three European countries have seen volumes surpassing the USD 1 billion mark including the UK (USD 10.4 billion), the Netherlands (USD 1.8 billion), and Germany (USD 1.2 billion), with France closely approaching this threshold with USD 933 million in 2018. Furthermore, from a regional perspective, despite relatively small domestic markets, the Nordic and Baltic States have exhibited strong growth. Here, regional volumes showed that the Nordics (Denmark, Finland, Iceland, Norway, and Sweden) accounted for USD 507 million in 2017 and USD 824 million in 2018, mostly led by Finland (USD 379 million) and Sweden (USD 298 million). The Baltics (Estonia, Latvia, and Lithuania) accounted for USD 265 million in 2017 and USD 539 million in 2018, with Latvia (USD 254 million) taking lead. Other notable regional leaders include Poland in Eastern Europe with USD 333 million and Spain in the Iberian Peninsula with USD 419 million. However, when controlling for market size, highest volumes per capita were recorded in the UK with USD 156, Latvia with USD 132, Estonia USD 121, and the Netherlands with USD 105 in 2018.

The fragmentation of crowdfunding markets in Europe can be grasped by distinguishing several categories of crowdfunding markets: (1) Market leaders - countries with a large crowdfunding volume, a few dozen platforms, and high volumes per capita (e.g. UK, Netherlands); (2) Domesticgrowth markets - countries with a large crowdfunding volume, a few dozen platforms, but low volume per capita mostly driven by domestic transactions (e.g. Germany, France); (3) International-growth marketscountries with small crowdfunding volumes, less than 20 platforms but high volume per capita mostly driven by international transactions (e.g. Estonia, Latvia); and (4) Slow international adapters - countries with small crowdfunding volumes, less than 20 platforms, and small volume 


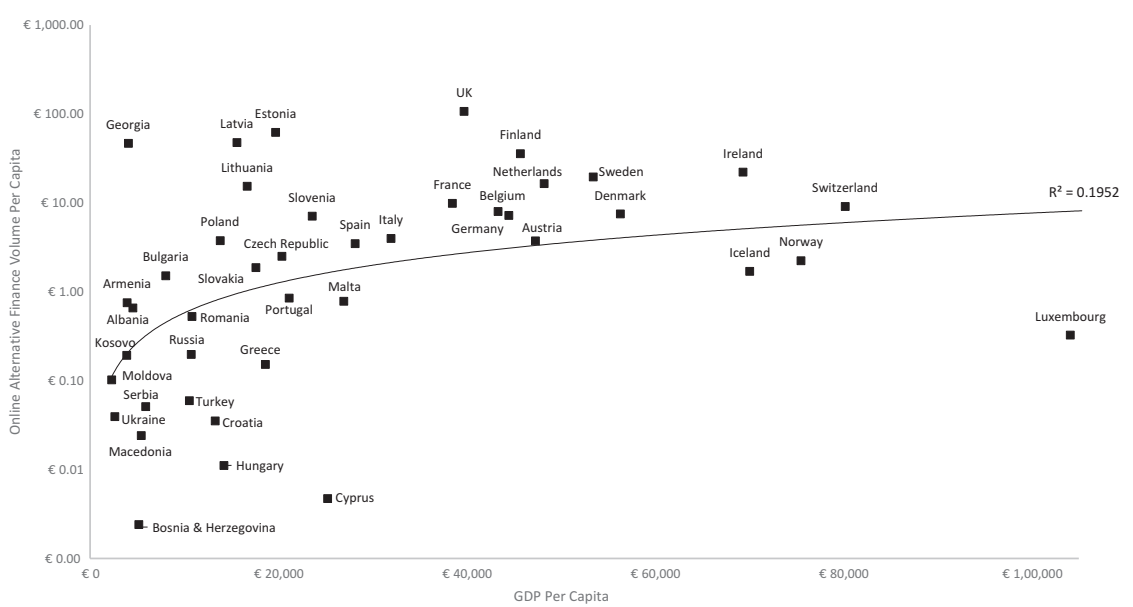

Fig. 16.1 Alternative finance volume per capita versus GDP per capita 2017. (Source: Ziegler et al. 2019)

per capita mostly driven by international transactions (e.g. countries in Central, Southern, and Eastern Europe) (Fig. 16.1).

When plotting per capita volumes against GDP per capita (Fig. 16.1), as indicator of economic development, the results suggest that volumes in countries such as the UK, Estonia, Latvia, Lithuania, and Georgia indicate an efficient utilization of the alternative finance models, whereas countries like Cyprus, Hungary, Bosnia and Herzegovina, and Luxembourg underutilized their alternative finance potential.

High volumes of P2P Consumer and Business Lending activities are associated with higher performance of a country (i.e. UK, Georgia, Latvia, and Estonia), while countries with high volumes of reward-based or donation-based crowdfunding are associated with relative underperformance of a country (i.e. Norway, Iceland, Malta, Greece, Luxembourg). This usually reflects regulatory regimes enabling investment crowdfunding versus regulatory environments in which this is constrained by existing laws, as well as where changes were made very close to data collection period. As a result, the underperformance of countries with large sectors of non-investment crowdfunding is caused by the fact that contributions per project per person are lower in the donation-based and reward-based models of crowdfunding as compared to investment models. 
The fragmentation is not only evidenced by the market volumes, but also by their distribution. It is instructive to observe which European countries represent the top three performing markets by volumes according to each crowdfunding model. In 2018, the UK took the top position in 10 of the 13 business models covered by the CCAF report. Germany took the top position in real estate crowdfunding and donation-based crowdfunding, as well as second position in P2P consumer and P2P business lending. And the Netherlands had the largest market for balance sheet property lending, while taking second place in the balance sheet business lending, debt-based securities, as well as the revenue sharing models. Other market leaders include those taking second place, such as Denmark in P2P property lending, Sweden in balance sheet consumer lending, Finland in equity crowdfunding, Italy in invoice trading, and France in reward crowdfunding.

Finally, a different insight into fragmentation in Europe is evident in a recent study by Rossi and Vismara (2018), who analysed services offered by 124 investment crowdfunding platforms from the UK, France, Germany, and Italy. First, they find that platforms offer relatively few services before, during, and after the campaign, and even these vary widely by platforms. The few exceptions offered by a majority of platforms include the facilitation of interaction and period campaign updates. Second, the study also showed that the average annual number of successful campaigns were substantially higher in the UK and France versus those in Germany and Italy. Furthermore, the authors found that platforms offering a higher number of post-campaign services were associated with higher number of successful campaigns, while the number of services offered before and during campaigns were not associated with higher levels of success.

\section{Traditional Financial Institutions in European Crowdfunding Markets}

Fragmentation in the European markets is also evident with respect to relations of platforms with institutional investors (e.g. pension funds, asset management firms, banks). In continental Europe in 2017 (i.e. 
excluding the UK), USD 511 million (13\%) originated from institutional investors, increasing in both relative and absolute size to USD 1.1 billion (14.5\%) in 2018. In 2018, these volumes reach USD 4.88 billion (47\%). Some markets are heavily dependent on institutional investors, including Italy with $90 \%$, the Benelux region with $88 \%$, and Germany with $64 \%$ of the 2018 volumes coming from institutional investors. On the other side of the spectrum, institutional investors were associated with only $2 \%$ of volumes in the CIS (Commonwealth of Independent States) and 5\% of volumes in Eastern and Baltic European countries in 2018.

Beyond the provision of funding to alternative finance offerings, institutional engagement with platforms is sometimes also evident with respect to organizational relations. Here, platform ownership by institutional partners is evident among $15-20 \%$ of platforms operating in Western Europe, but only among 4-8\% of platforms operating in Baltic, Central, and South-East Europe in 2017. No platform in Eastern Europe and the CIS was owned by institutional partners in 2017.

\section{International Scope of European Platform Operations}

Data collected annually by the CCAF suggests that cross-border transactions and internationalization of platforms is on the rise in Europe. In $2017,77 \%$ of platforms had seen cross-border inflows to local platforms, $44 \%$ of platforms saw cross-border outflows. Here, again, fragmentation is evident across Europe, where some regions are home to more internationally oriented platforms, while other regions are characterized by more domestic-facing platforms. In 2017, CIS countries, Georgia, Baltics, and Eastern European countries reported a high level of cross-border flows. Iberia, South-Eastern European countries, Ireland, Central European countries, and the Benelux countries showed a medium level of crossborder flows. Nordic countries, Germany, and France showed relatively low levels of cross-border flows. This is presented in Fig. 16.2. 


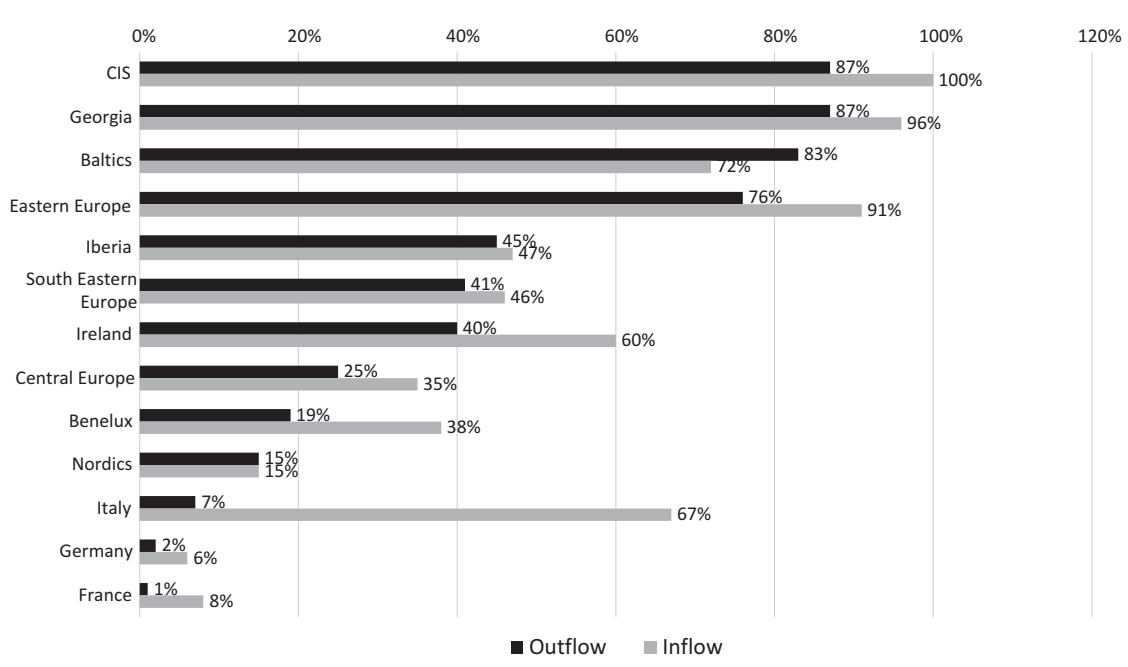

Fig. 16.2 Cross-border flows in European crowdfunding markets 2017. (Source: Ziegler et al. 2019)

These findings are especially relevant for the discussion of the ECSP Regime. According to our market classification suggested above, Market Leaders and Domestic-growth Markets incorporate a majority of domestic platforms first achieving a degree of scale operations domestically, and then engaging in cautious and limited international expansion. International-growth Markets include platforms that emerge from relatively small home markets, leveraging relatively permissive regulatory frameworks, while more aggressively expanding into other country markets for achieving scale, sustainability, and growth. Finally Slow International Adapters represent countries, where, despite scale potentialities, growth is constrained by lagging regulatory amendments as well as lower levels of social trust (Delhey and Newton 2005) and suspicion towards digital financial innovations. Here, platforms attempt tapping into international support to achieve legitimacy in the domestic markets, where international funding triggers domestic development and acceptance. 


\section{Regulation and European Crowdfunding Market Fragmentation}

Thus far, a number of areas in which disparity is evident within the European crowdfunding market have been listed including volumes per country and per capita, number of platforms, model diversity, and extent of dependency on cross-border transactions and flows. In the current section we will explore aspects of fragmentation with respect to regulations and their impact on a European-level market for crowdfunding. Ever since the first report mapping the conditions and prospects of crowdfunding in Europe, regulation was identified as a key pillar that must be addressed (De Buysere et al. 2012), so that appropriate rules and measures are put in place while ensuring the necessary protection of those interested in engaging in crowdfunding (Bruntje and Gajda 2016).

While economic theory suggests that a truly integrated market would reduce disparities considerably, local and regional differences can still occur. In an integrated market, platforms could offer their services across borders, investments would flow to the platform with the best offers, while allowing successful platforms to scale and outperform competitors. However, the motivation of local investors to provide funds to local businesses on local platforms might be higher than investing in businesses residing abroad or platforms abroad, even if both domestic and foreign platforms offer the same or better investment protections and services. Such phenomenon is known from investment research as a home bias (Tesar and Werner 1995), as well as 'not invented here' attitudes towards foreign ideas and technologies (Antons and Piller 2014).

Non-investment crowdfunding models such as those employed by donation- and reward-based platforms are the least constrained in terms of regulation. Platforms like Kickstarter, Indiegogo, Global Giving or GoFundMe, based in the US, have localized the user experience by translating the website into local languages, while operating under their respective international brands (Skotte and Juvik 2019). Donation- and reward-based crowdfunding does not require platforms to be supervised by the financial authorities or comply with investor protection regulation to the extent investment platforms are required to do. Platforms in donation-based and reward-based crowdfunding have to adhere to rules 
in the area of digital payments, but they partner with a payment provider which ensures regulatory compliance with European laws. There are very few exceptions where donation collection requires special permits such as in Denmark and Finland, but in most other European markets requirements are more flexible. Reward-based crowdfunding platforms have to comply with other European legal frameworks, such as the e-Commerce directive, Consumer rights directive, Copyright directive, or the Platform directive, which is currently under discussion. And although these directives have not been uniformly implemented across the European Union, such regulations haven't prohibited non-investment platforms to scale across Europe.

Most concerns with regulatory fragmentation are associated with investment crowdfunding. Here, the MiFID (2004/39/EC) and MiFID II (2014/65/EU) (Markets in Financial Instruments Directive) (European Commission 2018b) should have provided a unified framework for crowdfunding intermediaries. However, platforms and their industry associations provided evidence in the Impact Assessment of the European Commission that the MiFID-framework is not suitable to their business models. Member states have in the past 'gold-plated' MiFID by adding additional provisions for consumer protection, which made operation of platforms across border an even more demanding, costly, and less efficient process.

A second symptom of a regulatory fragmentation is the different national regimes under which platforms operate. A few member states of the European Union have implemented a bespoke regime for alternative finance service providers (e.g. UK, Finland, France), however, in most European member states a bespoke regime is still lacking, which generates regulatory uncertainty of platforms operating across borders. Furthermore, differences in national regulations across Europe have been argued to not only result in distortions of the market playing fields, but also limit economic growth that can be supported by cross-border offers of crowdfunding (Gajda 2017). In this context the CCAF report showed a clear positive association between crowdfunding volumes per capita and the level to which platforms evaluated local regulations as adequate (Ziegler et al. 2019). Overall, differences in regulatory regimes stem from disparities in licensing requirements, thresholds for prospectus requirements, as well as various consumer and investor protection provisions. 
Third, regulatory fragmentation can also be a result of activities of market participants. Platforms have created self-regulation frameworks, which are designed to induce trust in domestic platforms and possibly to establish a market entry barrier for foreign platforms. However, even selfregulation documents as enshrined in codes of conduct and ethics adopted by various industry organization across Europe exhibit significant differences in terms of scope, ambition, and oversight (Odorović and Wenzlaff 2020).

Against this backdrop, the European Union initiated the process towards establishing a pan-European regulatory regime in March 2018. The European Commission's Fin Tech Action Plan (European Commission 2018a) explicitly envisaged such goal as part of the European Capital Markets Union. More specifically, the ECSP Regime (European Commission 2018c) aimed to close the disparity in national regulations, provide robust investor protection, enable platforms to cater to clients in different countries holding a single licence, and allow small and innovative firms to raise funds across borders more effectively. Under such approach, the need to scale up regulatory compliance left limited room for opt-out provisions and partial harmonization in the case of the ECSP Regime.

The European Commission, in its proposal, suggested a passporting regime, similar to the existing MiFID regime for the offering and trading of equity and debt. The Commission proposal prohibited individual member states from adding regulatory requirements for platforms authorized as European Crowdfunding Service Providers. Such a prohibition would have created a level playing field between platforms operating in different states. It would also have curtailed regulatory arbitrage. However, in order to anticipate objection as a compromise with the Council, the Commission's proposal also allowed for the coexistence of national regulatory regimes. Accordingly, platforms wishing to stay within their respective existing regime, or operate only in one country, could stay within these national regulatory frameworks. The proposal by the Parliament sided with the Proposal by the Commission. The Council proposal went a different way. The Council instead proposed a harmonized regime with minimum standards, with member states having the option to increase the requirements on platforms operating in their countries. 
The proposed regulation by the Commission foresaw several unique solutions to the regulatory dilemma of harmonizing without stifling innovation. At the same time, the proposal left a few pertaining issues subject to further debate. The European Commission embraced the view that the regulation should focus more on the status and behaviour of crowdfunding intermediaries rather than fundraising firms. Despite substantially differing risk profiles, the proposal incorporated both lendingbased crowdfunding for businesses (known as P2P business lending) and equity-based crowdfunding. The blurry line of distinction between some debt and equity instruments justified equal regulatory treatment. However, P2P consumer lending remained outside the scope of the proposed regulation, although the business model of $\mathrm{P} 2 \mathrm{P}$ consumer lending is more similar to P2P business lending than to equity-based crowdfunding, and despite the fact that some entrepreneurs took P2P consumer loans to fund their small business ventures.

The critical aspect of investor protection under the proposed regulation is a high level of transparency at the platform and the project levels. Transparency rules serve to attenuate information asymmetry inherent in all financial markets. Investors have imperfect information about both the quality of projects seeking funding and the quality of platforms' services. Therefore, the regulation sets out distinctive transparency rules for project owners and platforms. Here, instead of costly prospectus requirements, project owners have to provide investors with a simplified key investor information sheet to enable them to make sound and informed investment decisions. In this context, another crucial discussion revolves around what should be the investment threshold that triggers the exemption from prospectus requirements. The European Commission proposed a threshold of 1 million euro per project per year. The European Parliament proposed a threshold of 8 million euro per year. The Council allowed member states to set the threshold between 1 million euro and 8 million euro per year. The negotiation concluded by setting a limit at 5 million euro per year and project.

With respect to prospective investors, the European Commission was concerned that retail investors do not understand the nature of crowdfunding investments and the risks they entail. For this reason, the regulation foresees an 'appropriateness test' (a concept also known under MiFID (II)) to be a part of the investors' onboarding procedure. Such a 
solution is an attempt to circumvent a more burdensome 'suitability test', which would imply that a platform estimates the financial situation of its clients and their ability to bear losses associated with crowdfunding investments.

Several provisions of the regulation referred to business requirements for platforms to ensure, among others, the impartiality before and continuity of business after the completion of a campaign. Given that platforms do not take any risk on their balance sheet, the European Commission deemed capital requirements redundant in case of crowdfunding, thus, leading to a sizable reduction of costs of market entry. The Council Proposal foresaw minimum operating capital, primarily to provide a continuation of the platform business in case of insolvency. In the end, the negotiation concluded with a minimum capital requirement of 25,000 euro.

At the time of writing this chapter, technical details were still emerging, all supporting the underlying notion that the ECSP will lead to a reduction of fragmentation. As a regulation (not a directive), it will be valid in all European member states 12 months after it is passed by the Council, Parliament, and Commission, with the option for each member state to extend the 12 month grace period to 24 months. It provides a unified definition of investment crowdfunding and of crowdfunding service providers. The ECSP regime sets a unified threshold for prospectus requirements at 5 million euro per year and per project. It also stipulates that member states cannot set forth individual investor thresholds.

The ECSP will be especially relevant for lending platforms, because it prohibits member states from requiring a banking licence from lendees or lenders, which will enable new platforms to merge. The conduct of platforms is regulated uniformly across European Union member states, especially in areas of regulatory uncertainty concerning the management of conflict of interest and relations with investors.

Finally, while of great benefit in reducing disparities with respect to investment crowdfunding across Europe, the ECSP will have little effect on P2P consumer lending, as well as on non-investment crowdfunding models, as they are not covered in the proposed regulation (Hooghiemstra 2019). In addition, a remaining loophole may result in that even in cases of investment crowdfunding for businesses, not all platforms will be covered in situations where member states decide that certain financial 
instruments are not deemed as securities, which are covered by the ECSP. Moreover, other critical regulatory aspects related to crowdfunding practice are also not covered by this regulation. For example, in terms of taxation, some European countries offer tax incentive schemes to investors and companies using crowdfunding (e.g. UK, France, Italy, Belgium, and Spain), while other countries do not, and even among those offering incentives, such schemes vary widely (Cicchiello et al. 2019).

\section{Outcomes of Crowdfunding in Europe}

Due to both sensitivity of information and the relative recency of the phenomenon, only limited evidence from a few studies is available about the outcomes of crowdfunding in European countries. Here, a study examining P2P loans in Lithuania from the Finbee P2P consumer lending platform (Gaigalienė and Česnys 2018) showed a default rate (defined as loan payment more than 90 days late) of $13 \%$ in a sample of 6324 loans analysed.

A different study examining 413 equity funded firms in Germany and the UK (Hornuf et al. 2018) found that overall 77 firms (18.8\%) successfully raised follow-up funding after the latest equity crowdfunding campaign, and 69 firms (16.7\%) went insolvent, were liquidated, or were dissolved. Furthermore, the study showed that, in comparison to UK firms, equity crowdfunded German firms stood a higher chance of raising follow-up funding from business angels or venture capital, but also had a higher likelihood of failure.

\section{Conclusions}

This chapter has presented evidence on the fragmented nature of European crowdfunding with respect to volumes, number of platforms, model composition and leadership, involvement of traditional financial institutions, dependency levels on cross-border transactions, and state of national regulation. However, while fragmentation in the European crowdfunding market was high in previous years, such disparities are expected to decrease with harmonized regulation and a boost in cross-border developments. 
The new rules laid out by the ECSP Regime hold promise to reduce fragmentation further, benefitting both large and small platforms towards healthier scale up supported by expansion to other European countries. Fragmentation in non-investment crowdfunding will likely continue, because of its exclusion from the ECSP regime, as well as the locally anchored nature of most of the small-scale fundraising initiatives characterizing non-investment models.

\section{Implications for Future Research}

While our review presents interesting insights about current realities in the European crowdfunding market, it also opens up opportunities for future research. Most importantly, there is the need for longitudinal study of market development dynamics, attempting to identify whether harmonization of regulation will indeed limit the extent to which the market is fragmented, as well as to what extent it will contribute to the international expansion of crowdfunding platforms across Europe. Other aspects in this context may relate to the study of the impact international platforms may have on local platforms, as international scope of investment may be more appealing to prospective fundraisers.

It will also be interesting to research the impact of clear and harmonized regulation on moves by traditional financial institutions, examining whether this will encourage them to enter the crowdfunding space and under which organizational and ownership formats. In this respect, it remains to be seen whether crowdfunding will deliver on its ideological promises of democratization of finance, or whether it will be overtaken by traditional actors with deeper pockets. This is especially relevant in mainland Europe, which has a long tradition of reliance on the banking system that can be used to enhance the legitimacy and credibility of crowdfunding actors among the general public.

In addition, more research is necessary on the outcomes of crowdfunding in the European context, capturing its short- and long-term effects on businesses, entrepreneurs, and investors. Such research remains rare and anecdotal, but of tremendous value for future platform development, policy making, and investor behaviour. 


\section{Implications for Practice}

First, investment crowdfunding platforms should follow the entry into force of the ECSP regulation in their respective countries, as well as countries they may wish to expand to, and adjust their operations accordingly. This implies developing strategies both for facing new competitors from neighbouring countries entering the platforms' home markets, as well as market entry strategies for countries they may wish to enter into themselves. Such strategies may include strategic partnerships, joint venturing, as well as platform mergers across Europe.

Second, once the greatest regulatory barriers have been addressed, platforms should focus attention on improving public education and understanding of crowdfunding to support its uptake in the various markets. Regulatory ambiguity may have been detrimental for participation in this market, and with such clarity platforms should engage in more strategic customer relationship management in terms of both retaining existing users, as well as recruiting new ones.

Finally, with greater regulatory clarity, opportunities for collaboration between traditional and alternative finance players are likely to increase. Here, platform operators should strike a delicate balance between being overpowered by deep pocket institutions that may want a stake in this new fast developing market, while remaining loyal to the original driving forces behind the market in terms of expanding access to finance, and greater sharing of profits with the wider public.

\section{References}

Antons, D., \& Piller, F. T. (2014). Opening the Black Box of "Not Invented Here": Attitudes, Decision Biases, and Behavioral Consequences. Academy of Management Perspectives, 29(2), 193-217.

Bruntje, D., \& Gajda, O. (2016). Crowdfunding in Europe: State of the Art in Theory and Practice. London: Springer International Publishing.

Cicchiello, A. F., Battaglia, F., \& Monferrà, S. (2019). Crowdfunding Tax Incentives in Europe: A Comparative Analysis. The European Journal of Finance, 25(18), 1856-1882. 
De Buysere, K., Gajda, O., Kleverlaan, R., et al. (2012). A Framework for European Crowdfunding. Retrieved from https://www.fundraisingschool.it/ wp-content/uploads/2013/02/European-Crowdfunding-FrameworkOct-2012.pdf.

Delhey, J., \& Newton, K. (2005). Predicting Cross-national Levels of Social Trust: Global Pattern or Nordic Exceptionalism? European Sociological Review, 21(4), 311-327.

Dushnitsky, G., Guerini, M., Piva, E., et al. (2016). Crowdfunding in Europe: Determinants of Platform Creation Across Countries. California Management Review, 58(2), 44-71.

European Commission. (2018a). FinTech Action plan: For a More Competitive and Innovative European Financial Sector. European Commission, Brussels. Retrieved from https://eur-lex.europa.eu/legal-content/EN/TXT/?uri=CEL EX:52018DC0109.

European Commission. (2018b). Investment Services and Regulated MarketsMarkets in Financial Instruments Directive (MiFID). European Commission, Brussels. Retrieved from https://ec.europa.eu/info/business-economy-euro/ banking-and-finance/financial-markets/securities-markets/ investment-services-and-regulated-markets-markets-financial-instrumentsdirective-mifid_en.

European Commission. (2018c). Proposal for a Regulation of the European Parliament and the Council on European Crowdfunding Service Providers (ECSP) for Business. European Commission, Brussels. Retrieved from https://eur-lex.europa.eu/resource.html?uri=cellar:0ea638be-22cb-11e8ac73-01aa75ed71a1.0003.02/DOC_1\&format=PDF.

European Parliament. (2019). European Crowdfunding Service Providers (ECSP) for Business. European Parliament, Brussels. Retrieved from https:// oeil.secure.europarl.europa.eu/oeil/popups/ficheprocedure.do?lang=en\&refe rence $=2018 / 0048(C O D)$.

Gaigalienė, A., \& Česnys, D. (2018). Determinants of Default in Lithuanian Peer-to-Peer Platforms. Management of Organizations: Systematic Research, 80(1), 19-36.

Gajda, O. (Ed.). (2017). Review of Crowdfunding Regulation: Interpretations of Existing Regulation Concerning Crowdfunding in Europe North America and Israel. Brussels: European Crowdfunding Network AISBL.

Hooghiemstra, S. N. (2019). Will the Proposed European Crowdfunding Regulation Lead to a 'true' European Market for Crowdfunding? July 25. Retrieved from https://papers.ssrn.com/sol3/papers.cfm?abstract_ id=3492981. https://doi.org/10.2139/ssrn.3492981. 
Hornuf, L., Schmitt, M., \& Stenzhorn, E. (2018). Equity Crowdfunding in Germany and the United Kingdom: Follow-up Funding and Firm Failure. Corporate Governance: An International Review, 26(5), 331-354.

Odorović, A. \& Wenzlaff, K. (2020). Joint Production of Confidence-SelfRegulation in European Crowdfunding Markets. Baltic Journal of Management, 15(2). https://doi.org/10.1108/BJM-04-2019-0119.

Rossi, A., \& Vismara, S. (2018). What Do Crowdfunding Platforms Do? A Comparison between Investment-based Platforms in Europe. Eurasian Business Review, 8(1), 93-118.

Skotte, R., \& Juvik, H. (2019). Localization of Crowdfunding Platforms: The Influencing Role of Culture, Institutions and Geography. Master's in Business Administration, University of Agder.

Tesar, L. L., \& Werner, I. M. (1995). Home Bias and High Turnover. Journal of International Money and Finance, 14(4), 467-492.

Ziegler, T., Shneor, R., Wenzlaff, K., et al. (2019). Shifting Paradigms-The 4th European Alternative Finance Benchmarking Report. Cambridge, UK: Cambridge Centre for Alternative Finance.

Ziegler, T., Shneor, R., Wenzlaff, K., et al. (2020). The Global Alternative Finance Benchmarking Report. Cambridge, UK: Cambridge Centre for Alternative Finance.

Open Access This chapter is licensed under the terms of the Creative Commons Attribution 4.0 International License (http://creativecommons.org/licenses/ by/4.0/), which permits use, sharing, adaptation, distribution and reproduction in any medium or format, as long as you give appropriate credit to the original author(s) and the source, provide a link to the Creative Commons licence and indicate if changes were made.

The images or other third party material in this chapter are included in the chapter's Creative Commons licence, unless indicated otherwise in a credit line to the material. If material is not included in the chapter's Creative Commons licence and your intended use is not permitted by statutory regulation or exceeds the permitted use, you will need to obtain permission directly from the copyright holder.

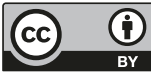

